\title{
Increasing levels of palm kernel cake (Elaeis guineensis Jacq.) in diets for feedlot cull cows
}

\author{
Laize V. Santos ${ }^{1 *}$, Robério R. Silva ${ }^{1}$, Fabiano F. Silva ${ }^{1}$, João Wilian D. Silva ${ }^{1}$, Daniele S. Barroso ${ }^{2}$, \\ Ana Paula G. Silva ${ }^{1}$, Sinvaldo O. Souza ${ }^{1}$, and Marceliana C. Santos ${ }^{1}$ \\ 'Universidade Estadual do Sudoeste da Bahia, Itapetinga, Bahia 45700-000, Brasil. \\ "Corresponding author (santos.laize@yahoo.com.br). \\ ${ }^{2}$ Universidade Federal Rural da Amazônia, Capanema 68700-030, Pará, Brasil.
}

Received: 13 March 2019; Accepted: 23 June 2019; doi:10.4067/S0718-58392019000400628

\begin{abstract}
Agro-industrial by-products are a great option for ruminant feeding. Alternative feedstuffs in ruminant diets are important to increase diets and reduce production costs. The present study evaluated different levels of palm (Elaeis guineensis Jacq.) kernel cake inclusion in diets for feedlot-finished cull cows and their implications on the intake and digestibility of dry matter (DM) and nutrients, as well as animal performance. The experiment was carried out in Ribeirão do Largo, Bahía, Brazil. Thirty-six Holstein $\times$ Zebu crossbred cows were assigned to four treatments at the rate of nine cows per treatment. The animals were fed sugarcane bagasse (roughage $15 \%$ ) and concentrate (85\%). The treatments were no addition of palm kernel cake, $8 \%, 16 \%$, or $24 \%$ palm kernel cake inclusion in the total DM diet. Palm kernel cake inclusion influenced DM and nutrient intakes, which responded quadratically. The digestibility of DM, crude protein, and neutral detergent fiber corrected for ash and protein showed a quadratic response and maximum digestibility at $1.67 \%, 5.24 \%$, and $3.68 \%$ cake inclusion levels, respectively; values decreased thereafter. The total digestible nutrients decreased linearly based on cake inclusion levels. Treatments affected final body weight, mean daily gain, and feed conversion, which showed a quadratic response to increasing levels of the by-product in the diet and maximum values were at $11.98 \%, 13.07 \%$, and $16.32 \%$ inclusion, respectively. Palm kernel cake is a viable alternative ingredient for animal biological efficiency. The $16 \%$ inclusion level in the total DM diet was the most appropriate for the finishing of cull cows in the feedlot.
\end{abstract}

Key words: Body weight, cattle, Elaeis guineensis, intake, performance.

\section{INTRODUCTION}

In view of the continuous demand for meat products, the beef cattle industry must efficiently produce animals to meet consumer market needs. The use of cull cows for meat production is an interesting strategy for the producer because these are adult animals that take less time to be finished and can thus fulfill market demands during the off-season periods.

However, the rationale of producing a sufficient quantity and quality of meat is difficult to achieve in tropical environments; this is mainly due to the seasonality of forage production because most of the meat produced in such systems originates from animals whose dietary base is pasture. Given the obvious difficulty of producing high-quality animals and supplying meat continuously throughout the year, nutritional and technological alternatives that are compatible with new market demands must be adopted. For example, animals can be produced in more intensive systems and nutritionally effective and lower cost alternative feedstuffs can be used (Chanjula et al., 2010; 2011).

Agro-industrial by-products are a great option for use in ruminant feeding because of their nutritional potential when added to the animal diet. Palm (Elaeis guineensis Jacq.) kernel cake is one such by-product that has been included in the diet of ruminants. This by-product is characterized for its great nutritive potential in animal feeding systems because it 
contains considerable levels of oil, fiber, and protein. However, despite its year-long availability, the efficient use of palm kernel cake in animal feeding is considerably limited due to the poor knowledge of its nutritional properties, performance of animals fed with this waste, and its economic value as a diet ingredient.

Rahman et al. (2013) observed an increase in crude protein intake by ruminants when palm kernel cake was included in the concentrate. In some studies evaluating the use of palm kernel cake in cattle diets, there were no effects of the byproduct on the DM and nutrient digestibility coefficients (Correia et al., 2011; Ferreira et al., 2012).

The hypothesis of this study was that moderate palm kernel cake inclusion levels (up to 24\%) in the diet could improve the performance of feedlot cull cows. Therefore, the objective of the present study was to investigate the effects of different levels of palm kernel cake inclusion in diets for feedlot-finished cull cows on DM and nutrient intake and digestibility, as well as animal performance.

\section{MATERIALS AND METHODS}

This research was conducted in full compliance with the Brazilian legislation on the use of animals adopted by the National Council for Animal Experimentation (CONCEA). It was previously approved by the Ethics Committee on Animal Use of the State University of Southwest Bahia under protocol 82/2015 approved on 15 April 2015.

The field trial was conducted on the Princesa do Mateiro farm located in the municipality of Ribeirão do Largo, southeast region of Bahia State, Brazil. Thirty-six Holstein $\times$ Zebu crossbred cows with a mean age of 83 mo (cows discarded for health problems) and mean live weight of $384.88 \pm 59.18 \mathrm{~kg}$ were included in the experiment. At the start of the experimental period, animals were identified by numbered plastic earrings, weighed, and then randomly assigned to four treatments in a completely randomized design (CRD) with nine replicates. The animals were distributed among the treatments so that all treatments had the same heterogeneity (body weight and age).

Cows were fed as a group and housed in collective stalls ( 9 animals per stall) with a usable area of $100 \mathrm{~m}^{2}(50 \mathrm{~m}$ partially covered and $50 \mathrm{~m}$ uncovered) equipped with covered feed troughs (10 linear meters) and concrete drinkers with a $250 \mathrm{~L}$ water capacity. The animals had $20 \mathrm{~d}$ to adjust to diets, stalls, and management, and this period was followed by $70 \mathrm{~d}$ of data collection for a total of 90 experimental days.

Cows were fed fresh sugarcane bagasse and concentrate (15:85 roughage:concentrate ratio). The following treatments were tested: $0 \%$ (control; no palm kernel cake inclusion), $8 \%, 16 \%$, or $24 \%$ palm kernel cake inclusion in the dry matter (DM) diet. The ingredients were balanced in the diets to supply the energy and protein requirements for the stipulated body weight gain $\left(1.0 \mathrm{~kg}_{\text {animal }}{ }^{-1} \mathrm{~d}^{-1}\right)$. The percentage composition of the dietary ingredients is shown in Table 1 . The chemical composition of the feedstuffs used in the experimental diets is described in Table 2.

The diets were formulated according to the NRC (2000) to meet the nutritional requirements for a daily gain of $1.0 \mathrm{~kg}$. Animals received the feed ad libitum, which was divided into two daily meals (07:00 and 15:00 h) to allow for 10\% as orts. The chemical composition of the experimental diets is given in Table 3 .

Table 1. Ingredient percentage composition in experimental diets (\% DM).

\begin{tabular}{lrrrr}
\hline & \multicolumn{4}{c}{ Palm kernel cake level (\%DM) } \\
\cline { 2 - 5 } Ingredient & 0 & 8 & 16 & 24 \\
\hline Sugarcane bagasse & 15.00 & 15.00 & 15.00 & 15.00 \\
Ground sorghum grain & 82.49 & 74.49 & 66.67 & 58.13 \\
Palm kernel cake & 0.00 & 8.00 & 16.00 & 24.00 \\
Soybean meal & 0.00 & 0.00 & 0.00 & 1.05 \\
Sodium bicarbonate & 0.95 & 0.94 & 0.93 & 0.92 \\
Urea & 0.94 & 0.75 & 0.57 & 0.24 \\
Mineral salt ${ }^{1}$ & 0.38 & 0.38 & 0.37 & 0.37 \\
Limestone & 0.24 & 0.25 & 0.25 & 0.25 \\
Total & 100.00 & 100.00 & 100.00 & 100.00 \\
\hline${ }^{1}$ Composition: 140 g Ca, 65 g P, $148 \mathrm{~g} \mathrm{Na}, 5 \mathrm{~g} \mathrm{Mg}, 12 \mathrm{~g} \mathrm{~S}, 107 \mathrm{mg} \mathrm{Co,} 1550$ \\
mg Cu, 150 mg I, 1400 mg Mn, 30 mg Ni, 18 mg Se, 4500 mg Zn, 1120 \\
mg, and 650 mg F (maximum).
\end{tabular}


Table 2. Feedstuff chemical composition in experimental diets (\%DM).

\begin{tabular}{lccrr}
\hline & $\begin{array}{c}\text { Sugarcane } \\
\text { bagasse }\end{array}$ & $\begin{array}{c}\text { Palm kernel } \\
\text { cake }\end{array}$ & $\begin{array}{c}\text { Soybean } \\
\text { meal }\end{array}$ & $\begin{array}{c}\text { Ground } \\
\text { sorghum }\end{array}$ \\
\hline DM & 54.68 & 91.29 & 86.03 & 86.40 \\
OM & 91.89 & 93.15 & 92.26 & 98.57 \\
CP & 1.37 & 14.66 & 52.52 & 7.77 \\
EE & 0.62 & 7.49 & 3.01 & 3.56 \\
NDFap & 79.49 & 67.64 & 14.07 & 12.47 \\
NFCap & 10.42 & 3.36 & 22.66 & 74.77 \\
Lignin & 11.65 & 19.83 & 0.54 & 1.19 \\
Ash & 8.11 & 6.85 & 7.74 & 1.43 \\
TND & 46.70 & 60.45 & 81.54 & 82.82 \\
\hline
\end{tabular}

OM: Organic matter; CP: crude protein; EE: ether extract; NDFap: neutral detergent fiber corrected for ash and protein; NFCap: non-fibrous carbohydrates corrected for ash and protein.

'TDN: Total digestible nutrients, estimated by the NRC equations (NRC, 2001).

Table 3. Chemical composition of diets (\%DM).

\begin{tabular}{lrrrr}
\hline & \multicolumn{4}{c}{ Palm kernel cake level (\%DM) } \\
\cline { 2 - 5 } Component (\%DM) & \multicolumn{1}{c}{0} & \multicolumn{1}{c}{8} & \multicolumn{1}{c}{16} & \multicolumn{1}{c}{24} \\
\hline Dry matter & 81.39 & 81.69 & 81.51 & 81.97 \\
Crude protein & 11.24 & 10.75 & 10.94 & 12.02 \\
Ether extract & 1.55 & 1.96 & 2.70 & 3.33 \\
NDFap & 34.38 & 40.32 & 41.15 & 50.53 \\
NFCap & 56.06 & 49.41 & 46.57 & 48.01 \\
Lignin & 3.82 & 6.90 & 7.65 & 9.86 \\
TDN & 72.44 & 72.99 & 65.65 & 69.73 \\
\hline
\end{tabular}

NDFap: Neutral detergent fiber corrected for ash and protein; NFCap: nonfibrous carbohydrates corrected for ash and protein; TDN: total digestible nutrients.

Samples of feed, orts, and feces were analyzed for the concentrations of DM, ashes, crude protein (CP), ether extract (EE), neutral detergent fiber corrected for ash and protein (NDFap), acid detergent fiber (ADF), and lignin according to the techniques described by the AOAC (1995). Non-fibrous carbohydrates corrected for ash and protein (NFCap) were calculated by the following formula described by Detmann and Valadares Filho (2010):

$$
\text { NFCap }=100-(\mathrm{CP} \%+\mathrm{EE} \%+\mathrm{MM} \%+\mathrm{NDFap})
$$

where all contents were corrected for ash and protein. Total digestible nutrients (TDN) were determined according to the NRC (2000):

$$
\mathrm{TDN}=(\mathrm{DCP}+(\mathrm{DEE} \times 2.25)+\mathrm{DNDF}+\mathrm{DNFC})
$$

where DCP is digestible crude protein, DEE is digestible ether extract, DNDF is digestible neutral detergent fiber, and DNFC is digestible non-fibrous carbohydrates.

The sample diet (supplied and orts) and feces were later incubated for $288 \mathrm{~h}$ inside non-woven fabric ('TNT') minibags $(5 \times 5 \mathrm{~cm})$ according to the method described by Detmann et al. (2012). Indigestible neutral fiber (iNDF) was used to estimate the daily DM intake of each animal. The remaining material from incubation was washed in running water until it was transparent again and then extracted in a neutral detergent solution; the residue was considered as iNDF. For this step, the following equation was used:

$$
\% \text { iNDF }=[(\mathrm{W} 3-(\mathrm{W} 1 \times \mathrm{C} 1)) \times 100] / \mathrm{W} 2
$$

where W1 is bag tare weight, W2 is sample weight, W3 is weight after the extraction process, and C1 is the correction of the blank bag (final bag weight after drying/original bag weight). The following formula was used to determine the total individual DM intake (TDMI):

$$
\mathrm{TDMI}=\left(\mathrm{FP} \times \mathrm{iNDF}_{\text {Feces }}\right) / \mathrm{iNDF}_{\text {Diet }}
$$

where $\mathrm{FP}$ is daily fecal production $\left(\mathrm{kg} \mathrm{d}^{-1}\right), \mathrm{NDF}_{\text {Feces }}$ is the indigestible neutral detergent fiber from the feces $(\mathrm{kg})$, and $\mathrm{iNDF}_{\text {Diet }}$ is the indigestible neutral detergent fiber from the diet $(\mathrm{kg})$. 
To estimate fecal production, chromium oxide $\left(\mathrm{Cr}_{2} \mathrm{O}_{3}\right)$ was used as an external marker that was supplied daily at 07:00 $\mathrm{h}$ in a single dose of $10 \mathrm{~g}$ per animal. The marker was placed inside paper cartridges and administered orally for $11 \mathrm{~d}$; the first $7 \mathrm{~d}$ were for the animals to adjust to the management and to regulate chromium excretion in the feces, followed by $5 \mathrm{~d}$ for collection (Vagnoni et al., 1997). Subsequently, excretion was calculated as proposed by Smith and Reid (1955) using the formula:

$$
\mathrm{FP}=\mathrm{CS} / \mathrm{CF}
$$

where FP is the daily fecal production $\left(\mathrm{g} \mathrm{d}^{-1}\right), \mathrm{CS}$ is the supplied chromium oxide $\left(\mathrm{g} \mathrm{d}^{-1}\right)$, and CF is the chromium oxide concentration in the feces $\left(\mathrm{g} \mathrm{g}^{-1} \mathrm{DM}\right)$.

Apparent nutrient digestibility (D) was determined by the formula described by Coelho da Silva and Leão (1979):

$$
\mathrm{D}=[(\mathrm{kg} \text { nutrient intake }-\mathrm{kg} \text { nutrient excretion }) / \mathrm{kg} \text { nutrient intake }]-100
$$

Cows were weighed at the start of the experimental period, $20 \mathrm{~d}$ later (diet adjustment period), and at the end of each 14-d period to monitor their weight gain. To evaluate animal performance during the experimental period, animals were deprived of solid feed and liquids for $12 \mathrm{~h}$ before the first and last weighing events. Mean daily gain (MDG) was determined as the difference between final body weight (FBW) and initial body weight (IBW) divided by the experimental period $(70 \mathrm{~d})$. Feed conversion (FC) was calculated as a function animal DM intake $\left(\mathrm{kg} \mathrm{d}^{-1}\right)$ and weight gain according to the following equation:

$$
\mathrm{FC}=(\mathrm{DMI} / \mathrm{MDG})
$$

where DMI is total daily DM intake $(\mathrm{kg})$ and MDG is mean daily gain $(\mathrm{kg})$.

The experimental design was completely randomized with four treatments and nine replicates and the analysis of variance and regression depended on the levels of palm kernel cake added to the animal diet. Results were interpreted statistically by regression analysis with the System for Statistical and Genetic Analysis (SAEG, 2000).

\section{RESULTS AND DISCUSSION}

Total DM intake, expressed both in $\mathrm{kg} \mathrm{d}^{-1}$ and as a percentage of body weight (\% $\left.\mathrm{BW}\right)$, had a quadratic response to the treatments and maximum values were observed at the palm kernel cake inclusion levels of $8.10 \mathrm{~kg} \mathrm{~d}^{-1}$ and $5.82 \%$, respectively. Beyond those levels, total DM intake declined (Table 4).

The reduction in DM intake (Table 4) may be a result of higher NDFap and lignin contents in the diets that received palm kernel cake (Table 3). The carbohydrates that constitute the plant cell wall are poorly degraded in the rumen and have a low rate of passage through the reticulorumen. Accordingly, diets with high concentrations of these ingredients promote decreased total DM intake due to the physical limitation caused by reticulorumen fill (Van Soest, 1994). Cunha et al. (2013) evaluated nutrient intake and digestibility for cows fed palm kernel cake $(0 \%, 11.34 \%, 22.78 \%$, and $34.17 \%$

\begin{tabular}{|c|c|c|c|c|c|c|c|c|c|}
\hline \multirow[b]{2}{*}{ Intake } & \multicolumn{4}{|c|}{ Palm kernel cake level (\%DM) } & \multirow[b]{2}{*}{ Equation* } & \multirow[b]{2}{*}{$\mathrm{CV}$} & \multicolumn{3}{|c|}{$\mathrm{P}^{1}$} \\
\hline & 0 & 8 & 16 & 24 & & & $\mathrm{R}^{2}$ & $\mathrm{~L}$ & Q \\
\hline TDM, $\mathrm{kg} \mathrm{d}^{-1}$ & 9.84 & 11.35 & 9.66 & 7.07 & 1 & 8.96 & 0.9721 & 0.0000 & 0.0000 \\
\hline TDM, \%BW & 2.33 & 2.49 & 2.13 & 1.77 & 2 & 15.89 & 0.9533 & 0.0004 & 0.0344 \\
\hline $\mathrm{CP}, \mathrm{kg} \mathrm{d}^{-1}$ & 1.10 & 1.22 & 1.05 & 0.85 & 3 & 8.70 & 0.9526 & 0.0000 & 0.0000 \\
\hline $\mathrm{EE}, \mathrm{kg} \mathrm{d}^{-1}$ & 0.15 & 0.23 & 0.26 & 0.24 & 4 & 10.32 & 1.0000 & 0.0000 & 0.0000 \\
\hline NDFap, $\mathrm{kg} \mathrm{d}^{-1}$ & 3.38 & 4.58 & 3.97 & 3.55 & 5 & 8.99 & 0.7665 & 0.9938 & 0.0000 \\
\hline NDFap, \%BW & 0.80 & 1.00 & 0.87 & 0.89 & $\hat{\mathrm{Y}}=0.89$ & 15.55 & - & 0.6748 & 0.0577 \\
\hline NFCap, $\mathrm{kg} \mathrm{d}^{-1}$ & 5.51 & 5.61 & 4.50 & 3.38 & 6 & 7.89 & 0.9779 & 0.0000 & 0.0003 \\
\hline $\mathrm{TDN}, \mathrm{kg} \mathrm{d}^{-1}$ & 7.13 & 8.29 & 6.34 & 4.92 & 7 & 7.88 & 0.8946 & 0.0000 & 0.0000 \\
\hline
\end{tabular}
cake inclusion based on total diet DM). The authors indicated a linear decrease in total DM intake with palm kernel cake

Table 4. Dry matter and nutrient intake by cull cows fed palm kernel cake.

TDM: Total dry matter; \%BW: relative to body weight; CP: crude protein; EE: ether extract; NDFap: neutral detergent fiber corrected for ash and protein; NFCap: non-fibrous carbohydrates corrected for ash and protein; TDN: total digestible nutrients; $\mathrm{CV}$ : coefficient of variation.

${ }^{1}$ Significant at the 5\% probability level; L: linear; Q: quadratic.

"Regression equations: (1) $\mathrm{y}=-0.016 \mathrm{x}^{2}+0.2594 \mathrm{x}+9.955$; (2) $\mathrm{y}=-0.002 \mathrm{x}^{2}+0.0233 \mathrm{x}+2.356$; (3) $\mathrm{y}=$ $-0.0012 x^{2}+0.0185 x+1.113 ;(4) y=-0.0004 x^{2}+0.0131 x+0.15 ;(5) y=-0.0063 x^{2}+0.1506 x+3.48 ;(6) y=$ $-0.0048 x^{2}+0.0206 x+5.57 ;(7) y=-0.0102 x^{2}+0.1369 x+7.31$ 
inclusion, which was correlated to a higher lignin/NDF ratio in diets with a higher level of inclusion of this by-product. On the other hand, Nunes et al. (2011) did not observe the effect of palm kernel cake inclusion on DM intake for lambs.

The lower DM intake exhibited by the animals of the control treatment (without palm kernel cake) is explained by ruminal acidosis and subsequent visible appearance of laminitis. The emergence of these disorders in animals that were not fed palm kernel cake in their diet may be due to the higher consumption of readily fermentable carbohydrates and lower NDFcp content of this diet.

The CP, EE, NDFap, NFCap, and TDN intake also responded quadratically to the treatments. The highest intake values of the respective components were obtained at the palm kernel cake inclusion levels of $7.70 \%, 16.37 \%, 11.95 \%, 2.14 \%$, and $6.71 \%$; intake decreased thereafter.

Maximum CP intake occurred at the palm kernel cake inclusion level of $7.70 \%$ in the diets (Table 4); CP intake declined beyond that level. This was a consequence of the highest total DM intake (expressed in $\mathrm{kg} \mathrm{d}^{-1}$ and \%BW) occurring near that point. Protein is a very important nutrient for animals to obtain satisfactory weight gain and a limited intake can therefore compromise animal performance. Bringel et al. (2011) reported similar results when evaluating palm kernel cake in ruminant diets. However, Rahman et al. (2013), in a study with ruminants, observed an increase in the CP intake with palm kernel cake inclusion in the concentrate.

The maximum EE intake at the $16.37 \%$ level (Table 4) represented $3.33 \%$ of the total DM from the ingested diet (Table 3 ), which is considered below the maximum limit of $5 \%$ to $6 \%$ deemed detrimental to ruminants. Thus, the decrease in DM intake cannot be correlated to EE intake by cows. Maciel et al. (2012) detected a linear decrease in DM intake of heifers fed palm kernel cake $(0 \%, 11.90 \%, 22.90 \%$, and $34.20 \%$ based on total dietary DM) when this by-product was included in the diet and which could be attributed to high EE levels of the cake.

The intake of NDFap $\left(\mathrm{kg} \mathrm{d}^{-1}\right)$ declined after the $11.95 \%$ level of palm kernel cake inclusion (Table 4) despite its increasing concentration in the diets (Table 3). According to Alimon (2004), it is estimated that $60 \%$ of palm kernel cake consists of cell wall components; this was demonstrated in the present study by their increase in the diets in which the by-product was included (Table 3). However, NDFap intake is limited by its characteristic of favoring rumen fill, which prevented higher intakes of fiber at that level.

Diets showed reduced NFCap content because of the fibrous nature of palm kernel cake (67.64\% NDFap) and its low NFCap concentration (3.36\%) (Table 3); this results in lower intake of these nutrients (Table 4) at the higher inclusion levels of the by-product. Non-fibrous carbohydrates are highly degradable components and important sources of energy for ruminants. Thus, a lower intake stemming from increased inclusion of the ingredient in the diets leads to decreased energy uptake for the animals, whose performance ultimately decreases.

After the $6.71 \%$ inclusion level, TDN intake decreased (Table 4) as a consequence of the reduction occurring in the dietary TDN content as the by-product inclusion levels increased. Total DM intake also declined after the 8.10 $\mathrm{kg} \mathrm{d}^{-1}$ and 5.82\% BW inclusion levels, thereby reducing TDN intake (Table 4). The TDN content in a diet indicates its nutritional value because it is correlated with the amount of digested nutrients; these nutrients are available for the animal metabolism. Nevertheless, animal performance is more deeply affected by variations in DM intake than by nutrient digestibility (Mertens, 1994).

No effects were observed on NDFap intake expressed as a percentage of body weight across the tested diets, with a mean of $0.89 \% \mathrm{BW}$. The digestibility coefficients of DM, CP, and NDFap had a quadratic response to the treatments and maximum digestibility was attained at the respective palm kernel cake inclusion levels of $1.67 \%, 5.24 \%$, and 3.68\%; values decreased beyond these levels (Table 5).

Results for DM digestibility (Table 5) showed the greater presence of less digestible components in the diets containing higher palm kernel cake levels (Table 3). Such components are represented by neutral detergent fiber and lignin, which both contribute to reducing the degradability of the supplied fiber. Non-structural carbohydrates, considered as highdegradability components, were also found to decrease as palm kernel cake was included in the diets. Although the control diet had a higher fiber and lignin content, its digestibility was lower compared to the $8 \%$ palm kernel cake treatment. This is probably due to the high fermentation of the non-fibrous carbohydrates, which made the rumen environment acidic, and impaired the efficient degradation of diet constituents.

Correia et al. (2011) and Ferreira et al. (2012), in a study evaluating the use of palm kernel cake in cattle diets, reported no effects of the by-product on the DM and nutrient digestibility coefficients. 
Table 5. Dry matter and nutrient digestibility coefficients of cull cows fed palm kernel cake.

\begin{tabular}{|c|c|c|c|c|c|c|c|c|c|}
\hline \multirow[b]{2}{*}{ Digestibility, \% } & \multicolumn{4}{|c|}{ Palm kernel cake level (\%DM) } & \multirow[b]{2}{*}{ Equation $^{*}$} & \multirow[b]{2}{*}{$\mathrm{CV}$} & \multicolumn{3}{|c|}{$\mathrm{P}^{1}$} \\
\hline & 0 & 8 & 16 & 24 & & & $\mathrm{R}^{2}$ & $\mathrm{~L}$ & Q \\
\hline DM & 69.80 & 70.94 & 63.91 & 58.89 & 1 & 5.45 & 0.9447 & 0.000 & 0.0166 \\
\hline $\mathrm{CP}$ & 67.79 & 66.58 & 65.57 & 55.14 & 2 & 7.57 & 0.9545 & 0.000 & 0.0073 \\
\hline $\mathrm{EE}$ & 79.39 & 81.40 & 78.83 & 79.97 & $\hat{Y}=79.89$ & 15.01 & - & 0.999 & 0.9981 \\
\hline NDFap & 56.04 & 60.59 & 49.84 & 47.24 & 3 & 7.49 & 0.7484 & 0.000 & 0.0115 \\
\hline NFCap & 85.74 & 85.40 & 82.14 & 91.49 & 4 & 3.99 & 0.7339 & 0.010 & 0.0001 \\
\hline TDN & 72.44 & 72.99 & 65.65 & 69.73 & 5 & 4.62 & 0.7548 & 0.003 & 0.1117 \\
\hline
\end{tabular}

CP: Crude protein; EE: ether extract; NDFap: neutral detergent fiber corrected for ash and protein; NFCap: non-fibrous carbohydrates corrected for ash and protein; TDN: total digestible nutrients; CV: coefficient of variation.

${ }^{1}$ Significant at the $5 \%$ probability level; L: linear; Q: quadratic.

"Regression equation: (1) $\mathrm{y}=\mathrm{b} 0.0241 \mathrm{x}^{2}+0.0805 \mathrm{x}+70.309 ;(2) \mathrm{y}=-0.036 \mathrm{x}^{2}+0.3774 \mathrm{x}+67.309 \mathrm{R}^{2}=0.9545$;

(3) $y=-0.0279 x^{2}+0.2059 x+57.212 ;(4) y=0.0379 x^{2}-0.7336 x+86.516 ;(5) y=-0.1934 x+72.523$.

The reduction of CP digestibility after the $5.24 \%$ palm kernel cake inclusion (Table 5) is related to the unavailable protein content in the by-product because palm cake has a large part of this nutrient complexed to the cell wall in its unavailable form, which reduces its access by rumen microorganisms. According to Maciel et al. (2012), the best use of CP shows a negative correlation with the nitrogenous fibrous matter content of the food, which contributes to decreased protein digestibility in diets containing palm kernel cake.

The reduced NDFap digestibility coefficient (Table 5), is explained by the considerable amounts of lignin present in the cake (19.83\%). Lignin binds to cell wall carbohydrates and has a negative effect on the digestibility of the fibrous fraction because it is an indigestible phenolic compound. The lignin content increased (Table 3) with palm kernel cake inclusion in the diet, which suggests lower NDFap digestibility at higher inclusion levels. Similar results were found by Rahman et al. (2013) when evaluating NDFcp digestibility in diets for ruminants fed with increasing levels of palm kernel cake.

According to Santos et al. (2017), NDF from tropical feedstuffs is characterized by highly heterogeneous degradation, which is responsible for significant changes in the rumen-reticulum; it first influences potentially digestible NDF, which provides energy to animals by breaking down fiber carbohydrates, and secondly affects the indigestible portion of NDF that is unable to be utilized by rumen microorganisms.

There was no effect of palm kernel cake inclusion in the diets on the EE digestibility coefficient, which had a mean of $79.89 \%$. The NFCap digestibility coefficient was influenced by the diet and exhibited a quadratic effect with a minimum value at the $9.67 \%$ level. Beyond that level, this variable started to increase. The increase in the NFCap digestibility coefficient (Table 5) beyond the $9.67 \%$ level is explained by the reduction of total DM intake $\left(\mathrm{kg} \mathrm{d}^{-1}\right)$ that occurred after the $8.10 \%$ level, which led to improved feed utilization by the rumen microorganisms. According to Bringel et al. (2011), there is a compensatory effect on animals in which lower DM intake improves food utilization by the ruminal microbiota, providing better nutrient digestibility, as it occurred for the NFCap digestibility coefficient.

Total digestible nutrients decreased linearly with increasing levels of palm kernel cake added to the diet. Every $1 \%$ of added cake led to a $0.1934 \%$ decrease in TDN (Table 5). This is a consequence of inserting slow-digestion components into the diet with the inclusion of the by-product, such as the high levels of NDFap and lignin. In addition, the large portion of protein that is unavailable for digestion reduces its utilization and ultimately the total digestible nutrient content.

Treatments affected final body weight, mean daily gain, and feed conversion (Table 6), which showed a quadratic response to the increasing levels of the by-product in the diet and maximum values were observed at $11.98 \%, 13.07 \%$, and $16.32 \%$ inclusion, respectively. The higher final body weight and mean daily gain shown by the animals at the respective $11.98 \%$ and $13.07 \%$ inclusion levels are associated with DM intake and better utilization of the nutrients available to them. After its maximum point at $13.07 \%$ palm kernel cake inclusion in the diets, mean daily gain started to decrease, which can be explained by the nutritional characteristics of the cake, such as high concentrations of lignified fiber, low levels of easily fermentable carbohydrates, low digestibility of the fibrous fraction and protein, and total digestible nutrient content.

Santos et al. (2016) indicated a linear decrease for the final weight gain and mean daily gain of lambs fed with increasing levels of palm kernel cake. These results were explained by the decrease in total DM intake and total nutrient digestibility 
Table 6. Performance of cull cows fed diets with different levels of palm kernel cake.

\begin{tabular}{|c|c|c|c|c|c|c|c|c|c|}
\hline \multirow[b]{2}{*}{ Performance } & \multicolumn{4}{|c|}{ Palm kernel cake level (\%DM) } & \multirow[b]{2}{*}{ Equation* } & \multirow[b]{2}{*}{$\mathrm{CV}$} & \multicolumn{3}{|c|}{$\mathrm{P}^{1}$} \\
\hline & 0 & 8 & 16 & 24 & & & $\mathrm{R}^{2}$ & $\mathrm{~L}$ & Q \\
\hline IBW, kg & 382.2 & 405.3 & 380.3 & 371.7 & $\hat{Y}=384.88$ & - & - & - & - \\
\hline FBW, kg & 441.4 & 504.0 & 488.1 & 446.3 & 1 & 13.44 & 0.9517 & 1.0000 & 0.0186 \\
\hline MDG, $\mathrm{kg} \mathrm{d}^{-1}$ & 0.846 & 1.410 & 1.540 & 1.066 & 2 & 27.13 & 0.9952 & 0.1179 & 0.0004 \\
\hline $\mathrm{FC}, \mathrm{kg} \mathrm{kg}^{-1}$ & 13.26 & 8.42 & 6.59 & 8.18 & 3 & 42.51 & 0.9997 & 0.0057 & 0.0183 \\
\hline
\end{tabular}

IBW: Initial body weight; FBW: final body weight; MDG: mean daily gain; FC: feed conversion; CV: coefficient of variation.

${ }^{1}$ Significant at the $5 \%$ probability level; L: linear; Q: quadratic.

"Regression equations: (1) $y=-0.4078 x^{2}+9.7725 x+444.03 R^{2} ;(2) y=-0.0041 x^{2}+0.1072 x+0.8375 ;(3) y$ $=0.0251 \mathrm{x}^{2}-0.8162 \mathrm{x}+13.281$.

of the diets containing the cake compared with the control treatment. On the other hand, Macome et al. (2011) did not mention any differences in weight gain for lambs fed with palm pie, which can be due to the non-differentiation for the total digestible nutrient intake among the diets; this implies the same energy intake, a highly important fraction to increase animal weight gain. The lowest feed conversion at the $16.32 \%$ palm kernel cake inclusion level in the diets (Table 6) is directly linked to the transformation of the consumed feedstuff into weight gain. This indicates that the dietary nutrients were best utilized at the $16.32 \%$ inclusion level, which had a positive effect on final body weight and mean daily gain.

At the $16.32 \%$ palm kernel cake inclusion level in the diet, the maximum feed conversion rate was observed (approximately $6.6 \mathrm{~kg}$ feed $\mathrm{kg}^{-1}$ gain); these results were similar to those observed for finishing young animals (Cruz et al., 2014; Callegaro et al., 2015; Cullmann et al., 2017; D’Áurea et al., 2017).

\section{CONCLUSIONS}

Moderate levels of palm kernel cake are a viable alternative in ruminant diets for animal biological efficiency. The $16 \%$ level in the total DM diet is the most appropriate for the finishing of cull cows in the feedlot, positively influencing animal performance.

\section{ACKNOWLEDGEMENTS}

The authors thank CAPES (Coordination for the Improvement of Higher Education Personnel) and the State University of Southwest Bahia.

\section{REFERENCES}

Alimon, AR. 2004. The nutritive value of palm kernel cake for animal feed. Palm Oil Developments 40:12-14.

AOAC. 1995. Official methods of analysis of AOAC International. 16 $6^{\text {th }}$ ed. Association of Official Analytical Chemists (AOAC), Arlington, Virginia, USA.

Bringel, L.M.L., Neiva, J.N.M., Araújo, V.L., Bomfim, M.A.D., Restle, J., Ferreira, A.C.H., et al. 2011. Consumo, digestibilidade e balanço de nitrogênio em borregos alimentados com torta de dendê em substituição à silagem de capim-elefante. Revista Brasileira de Zootecnia 40:1975-1983.

Callegaro, A.M., Alves Filho, D.C., Brondani, I.L., Silveira, M.F., Pizutti, L.A.D., Paula, P.C., et al. 2015. Consumo e desempenho de novilhos alimentados com borra de soja em confinamento. Semina: Ciências Agrárias 36:2055-2066. doi:10.5433/1679-0359.2015v36n3Supl1p2055.

Chanjula, P., Mesang, A., and Pongprayoon, S. 2010. Effects of dietary inclusion of palm kernel cake on nutrient utilization, rumen fermentation characteristics and microbial populations of goats fed Paspalum plicatulum hay-based diet. Songklanakarin Journal of Science and Technology 32:527-536.

Chanjula, P., Siriwathananukul, Y., and Lawpetchara, A. 2011. Effect of feeding rubber seed kernel and palm kernel cake in combination on nutrient utilization, rumen fermentation characteristics, and microbial populations in goats fed on Briachiaria humidicola hay-based diets. Asian-Australasian Journal of Animal Science 24:73-81. doi.org/10.5713/ajas.2011.10171.

Coelho da Silva, J.F., e Leão, M.I. 1979. Fundamentos de nutrição dos ruminantes. Livroceres, Piracicaba, Brasil. 
Correia, B.R., Oliveira, R.L., Jaeger, S.M.P.L., Bagaldo, A.R., Carvalho, G.G.P., Oliveira, G.J.C., et al. 2011. Consumo, digestibilidade e $\mathrm{pH}$ ruminal de novilhos submetidos a dietas com tortas oriundas da produção do biodiesel em substituição ao farelo de soja. Arquivo Brasileiro de Medicina Veterinária e Zootecnia 63:356363. http://dx.doi.org/10.1590/S0102-09352011000200013.

Cruz, R.S., Alexandrino, E., Missio, R.L., Restle, J., Melo, J.C., Paula Neto, J.J., et al. 2014. Desempenho bioeconômico de tourinhos alimentados com níveis de concentrado e farelo do mesocarpo de babaçu. Semina: Ciências Agrárias 35:21592174. doi:10.5433/1679-0359.2014v35n4p2159.

Cullmann, J.R., Kuss, F., Moletta, J.L., Lançanova, J.A.C., Silveira, M.F., Meneses, L.F.G., et al. 2017. Produção de novilhos castrados ou não castrados terminados em confinamento em idade jovem ou superjovem. Arquivo Brasileiro de Medicina Veterinária e Zootecnia 69:155-164. doi.org/10.1590/1678-4162-9100.

Cunha, O.F.R., Neiva, J.M.N., Maciel, R.P., Restle, J., Araújo, V.L., Paiva, J., et al. 2013. Torta de dendê (Elaeis guineensis L.) em dietas de vacas leiteiras. Semina: Ciências Agrárias 34:445-454. doi:10.5433/1679-0359.2013v34n1p445.

D’Áurea, A.P., Ezequiel, J.M.B., D’Áurea, E.M.O., Santos, V.C., Fávaro, V.R., Homem Júnior, A.C., et al. 2017. Glicerina bruta associada à ureia na terminação de bovinos: consumo, desempenho e características da carne. Arquivo Brasileiro de Medicina Veterinária e Zootecnia 69:165-172. http://dx.doi.org/10.1590/1678-4162-8895.

Detmann, E., and Valadares Filho, S.C. 2010. On the estimation of non-fibrous carbohydrates in feeds and diets. Arquivo Brasileiro de Medicina Veterinária e Zootecnia 62:980-984. http://dx.doi.org/10.1590/S0102-09352010000400030.

Detmann, E., Souza, M.A., Valadares Filho, S.C., Queiroz, A.C., Berchielli, T.T., Saliba, E.O.S., et al. 2012. Métodos para análise de alimentos. Instituto Nacional de Ciência e Tecnologia de Ciência Animal Ciência Animal (INCT-CA), Suprema, Visconde do Rio Branco, Brasil.

Ferreira, A.C., Lopes, R., Regina, A., Pinto, G., Vaz, S.R., and Andrade, P. 2012. Intake, digestibility and intake behaviour in cattle fed different levels of palm kernel cake. Revista MVZ Córdoba 17:3105-3112.

Maciel, R.P., Neiva, J.M.N., Araújo, V.L., Cunha, O.F.R., Paiva, J., Restle, J., et al. 2012. Consumo, digestibilidade e desempenho de novilhas leiteiras alimentadas com dietas contendo torta de dendê. Revista Brasileira de Zootecnia 41:698-706. doi.org/10.1590/S1516-35982012000300033.

Macome, F., Lopes, R., Regina, A., Leal, G.G., Pires, L.B., and Alves, M.A. 2011. Productive performance and carcass characteristics of lambs fed diets containing different levels of palm kernel cake. Revista MVZ Córdoba 16:2659-2667.

Mertens, D.R. 1994. Regulation of forage intake. In Fahey, G.C. (ed.) Forage quality, evaluation and utilization. American Society of Agronomy, Crop Science Society of America, Soil Science Society of America, Madison, Wisconsin, USA.

NRC. 2000. Nutrient requirements of beef cattle. National Research Council (NRC), National Academies of Sciences, Engineering, and Medicine, Washington, D.C., USA.

NRC. 2001. Nutrient requirements of dairy cattle. National Research Council (NRC), National Academies of Sciences, Engineering, and Medicine, Washington, D.C., USA.

Nunes, A.S., Oliveira, R.L., Borja, M.S., Bagalso, A.R., Macome, F.M., Jesus, I.B., et al. 2011. Intake, digestibility and blood parameters of lambs fed diets with palm kernel. Archivos de Zootecnia 60:903-912.

Rahman, M.M., Abdullah, R.B., Embong, W.K.W., Nakagawa, T., and Akashy, R. 2013. Effect of palm kernel cake as protein source in a concentrate diet on intake, digestibility and live weight gain of goats fed Napier grass. Tropical Animal Health and Production 45:873-878. doi:10.1007/s11250-012-0300-4.

SAEG. 2000. Sistema de análises estatísticas e genéticas. Versão 8.0. Manual do Usuário. Universidade Federal de Viçosa (UFV), Viçosa, Minas Gerais, Brasil

Santos, R.C., Alves, C.S., Mezzomo, R., Oliveira, L.R.S., Cutrim, D.O., Gomes, D.I., et al. 2016. Performance of feedlot lambs fed palm kernel cake-based diets. Tropical Animal Health and Production 48:367-372. doi:10.1007/s11250-015-0960-y.

Santos, R.C., Gomes, D.I., Alves, K.S., Mezzomo, R., Oliveira, L.R.S., Cutrim, D.O., et al. 2017. Carcass characteristics and meat quality of lambs that are fed diets with palm kernel cake. Asian-Australasian Journal of Animal Science 30:865-871. https://doi.org/10.5713/ajas.16.0424.

Smith, A.M., and Reid, J.T. 1955. Use of chromic oxide as an indicator of fecal output for the purpose of determining the intake of a pasture herbage by grazing cows. Journal of Dairy Science 38:515-524. https://doi.org/10.3168/jds.S0022-0302(55)95006-2.

Vagnoni, D.B., Broderick, G.A., Clayton, M.K., and Hatfield, R.D. 1997. Excretion of purine derivatives by Holstein cows abomasally infused with incremental amounts of purines. Journal of Dairy Science 80:1695-1702.

Van Soest, P.J. 1994. Nutritional ecology of the ruminant. Cornel University Press, Ithaca, New York, USA. 